\section{Regards sur l'économie allemande}

Bulletin économique du CIRAC

$67 \mid 2004$

Varia

\title{
Médias et information
}

Deutscher Fachjournalisten-Verband (ed.), Fachjournalismus.

Expertenwissen professionell vermitteln / MEYN Hermann, Massenmedien in Deutschland

\section{(2) OpenEdition}

1 Journals

Édition électronique

URL : http://journals.openedition.org/rea/3827

DOI : 10.4000/rea.3827

ISBN : 978-2-8218-0830-0

ISSN : 1965-0787

Éditeur

CIRAC

Édition imprimée

Date de publication : 1 juillet 2004

ISSN : 1156-8992

Référence électronique

"Médias et information », Regards sur l'économie allemande [En ligne], 67 | juillet 2004, mis en ligne le 08 octobre 2009, consulté le 22 septembre 2020. URL : http://journals.openedition.org/rea/3827 DOI : https://doi.org/10.4000/rea.3827

Ce document a été généré automatiquement le 22 septembre 2020.

(c) CIRAC 


\section{Médias et information}

Deutscher Fachjournalisten-Verband (ed.), Fachjournalismus.

Expertenwissen professionell vermitteln / MEYN Hermann, Massenmedien in Deutschland

\section{RÉFÉRENCE}

Deutscher Fachjournalisten-Verband (ed.), Fachjournalismus. Expertenwissen professionell vermitteln, Coll. Praktischer Journalismus, vol. 58, UVK Verlagsgesellschaft mbH, Constance, 2004, $358 \mathrm{p}$.

MEYN Hermann, Massenmedien in Deutschland, UVK Verlagsgesellschaft mbH, Constance, 2004, $294 \mathrm{p}$.

1 Le paysage médiatique allemand évolue tellement vite que $\mathrm{H}$. MEYN en est contraint d'actualiser presque tous les ans son 'classique'. En voici donc la réédition 2004, augmentée d'une analyse de la tendance à la médiatisation du politique qu'on peut observer depuis les élections au Bundestag de l'automne 2002. Une autre tendance des médias allemands est le boom de la presse spécialisée, déclenché voici une dizaine d'années. Voici le premier manuel consacré au journalisme spécialisé et à ses nouvelles perspectives professionnelles, publié chez l'éditeur spécialisé UVK. (IB) 